\title{
Travel Experiences and Quality of Destination as Antecedent of Satisfaction of Tourist Visiting Culinary Tourism Destinations
}

\author{
Abd.Hamid ${ }^{1}$ Ummasyroh $^{1}$ Jusmawi Bustan ${ }^{1}$ Heri Setiawan ${ }^{1, *}$ \\ ${ }^{1}$ Business Administration Department, State Polytechnic of Sriwijaya \\ "Corresponding author. Email: heri.setiawan@polsri.ac.id
}

\begin{abstract}
Culinary is one of the attractions and tourist attractions that attract tourists to visit tourist destinations. Culinary tours offer a variety of unique local culinary delights for tourists to enjoy. This study was triggered to explore the extent to which tourist experiences and destination quality perceived by tourists during their visit to culinary tourism destinations will boost the level of tourist satisfaction. The sample technique applied in this study used a purposive sampling method with a sample size of 216 domestic tourists. This study explains that experience of tourists has an important effect on satisfaction of tourist. In addition, the quality of the destination also has a crucial effect on satisfaction of tourist.
\end{abstract}

Keywords: travel experience, quality of destination, tourist satisfaction, culinary tourism.

\section{INTRODUCTION}

One of the sectors that the government relies on to be able to increase foreign exchange is tourism. Sustainable tourism development is expected to have a positive impact on Indonesia's economic development. The tourism sector is able to provide an important foreign exchange contribution to the country, increasing employment and increasing people's income [1]. Therefore, in managing tourist destinations, managers are required to be able to take advantage of opportunities and create breakthroughs to attract tourists to visit the destination. Managers must be careful in offering various uniqueness to tourists so that they will provide a memorable tourist experience. The experiences felt by tourists during their visit to tourist destinations play a role in increasing the interest in returning tourists [2]. The experience of tourists visiting a tourist destination is an important indicator of tourists for vacation turn back to the same destination hereafter [3]. Therefore, destination managers must understand about the good memorable tourist experiences that tourists get so that they can attract tourist behavioral intentions to return to tourist destinations. Tourist destination managers must also be able to attract tourists who have visited the destination by developing various attractions [4]. Tourists who have visited a tourist destination tend to share experiences with friends, family and other tourists through word of mouth [5]. The management of tourist destinations must be able to provide a memorable tourism experience in the minds of tourists so that it will encourage a higher level of tourist satisfaction [6]. Experiences and stories remembered by tourists after visiting tourist destinations need to be studied to determine the interest in tourist behavior [7]. Accordingly, it is notable to tourist destination administrator to improve service quality and tourist satisfaction levels [8]. Higher quality service levels are believed to drive overall tourist satisfaction levels, and indirectly lead to higher loyalty [9].

\section{LITERATURE REVIEW AND HYPOTHESIS}

Travel Experience and Tourist Satisfaction

Previous research has explained that experience is one of the factors driving consumers to increase satisfaction [10]. Various studies have empirically found a significant connection amongst emotions and customer satisfaction [11; [12]. The relationship between emotions and consumer behavior intention has been empirically studied by previous research [13]; [14]. [15] describe if consumers are satisfied and have a positive experience while using a product or service, 
then consumers tend to return to using it. [16] explains that visitors who enjoy a good sports tourism experience are likely to come back in the future. [17] have examined the relationship between perceptions of tourists' travel experiences and the satisfaction of visiting natural tourist destinations. Based on some of the studies above, it can be hypothesized:

$\mathrm{H} 1$ : Tourism experience is related to satisfaction of tourist

Quality od Destination and Satisfaction of Tourist

The connexion in quality of destination and satisfaction of tourist has been studied in various studies, for example, festival activities [18], sports and recreation centers [19], cultural centers [20] and natural tourist destinations [21]. [22] conducted a study on the intercourse between quality of destination, satisfaction of tourist and tourist behavior intentions in the scene of countryside tourist destinations in Malaysia. The findings of the study show that quality of destination has a significant lineal and subordinate effect on satisfaction and intention of behavioral. Research by [23] also states that there is an association in the middle of quality of destination and satisfaction of tourist. [24] proposes a lineal and beneficial link between perception of quality and loyalty, and a circumstantial absolute correlation betwixt quality of perception, gratification and loyalty. [25] show that there is a absolute connection among quality of perception and satisfaction, and quality in connection with intention of behavioral. [26]; [27] set up a crucial positive relation between satisfaction and apprehend of quality, implicit that traveler who identify higher quality of destination are increased probable to experience considerable satisfaction. Based on the above study, it can be hypothesized:

$\mathrm{H} 2$ : Destination quality is related to tourist satisfaction

\section{METHODS}

Population and Samples

The target population of this research is domestic travelers who have come to see culinary tourism destinations in City of Palembang. The research data collection was carried out continuously for one month. The sampling technique with a purposive approach was utilized to assign the respondents with a number of analysis samples as many as 216 individuals. The questionnaire about tourism experiences was adopted from [28]; [1] and measured by 6 question items. The questionnaire on destination quality was adapted from [25]. The questionnaire on tourist satisfaction was adapted from [25] and measured by 6 question items.
Analysis of Data

Data from the distribution of questionnaires were analyzed to assessment the validity and reliability of instrument. Descriptive interpretation was undertaken to determine the characteristics of the respondent. Then an inferential statistical analysis was carried out using multiple regression methods. with the help of SPSS 22.00 software.

\section{RESULTS}

\section{Respondent Characteristics}

Based on the number of respondents as many as 216 people can be explained that 68 people are male and 148 are female. The largest number of respondents was 1622 years old with 132 people and 48 people over 43 years old. The highest respondent's education is Senior high school with 104 people and post graduate with 67 people. Most respondents occupy a student / student number with 111 people and followed by government officers with a total of 61 people. the intensity of visits to culinary tourism destinations is more than 3 times a total of 127 people. The tourist destination area most visited by tourists is the Kuto Besak Fort with 97 people and the 26 Ilir culinary area with 90 people

Validity and Reliability

The results of the analysis of the instrument validity test for all the variable indicators studied show that they have met the specified value requirements. Then, to examine the reliability of all variables, indicators had exceeded the minimum requirements. It can be seen that the value obtained is above 0.60 .

Table 1 validity test

\begin{tabular}{|c|c|c|c|}
\hline Variable & Indicator & Validity score & Conc \\
\hline \multirow{5}{*}{$\begin{array}{l}\text { Tourism } \\
\text { Experience }\end{array}$} & TE1 & 0.763 & \multirow{5}{*}{ Valid } \\
\hline & TE2 & 0.784 & \\
\hline & TE3 & 0.728 & \\
\hline & TE4 & 0.497 & \\
\hline & TE5 & 0.767 & \\
\hline \multirow{4}{*}{$\begin{array}{l}\text { Destination } \\
\text { Quality }\end{array}$} & DQ1 & 0.862 & \multirow{4}{*}{ Valid } \\
\hline & DQ2 & 0.896 & \\
\hline & DQ3 & 0.887 & \\
\hline & DQ4 & 0.826 & \\
\hline \multirow{5}{*}{$\begin{array}{l}\text { Tourist } \\
\text { Satisfaction }\end{array}$} & TS1 & 0.876 & \multirow{5}{*}{ Valid } \\
\hline & TS2 & 0.792 & \\
\hline & TS3 & 0.826 & \\
\hline & TS4 & 0.622 & \\
\hline & TS5 & 0.862 & \\
\hline
\end{tabular}

Table 2 reliability test

\begin{tabular}{|l|l|}
\hline Variable & Cronbach $\boldsymbol{\alpha}$ \\
\hline Tourism experience & 0.756 \\
\hline Destination Quality & 0.886 \\
\hline Tourist Satisfaction & 0.839 \\
\hline
\end{tabular}


Table 3 linear regression analysis

\begin{tabular}{|c|c|c|c|c|}
\hline Independent & Dependent & $\mathrm{B}$ & t-value & Sig. \\
\hline $\begin{array}{l}\text { Tourism } \\
\text { Experience }\end{array}$ & $\begin{array}{l}\text { Tourist } \\
\text { Satisfaction }\end{array}$ & 0.469 & 9.787 & 0.000 \\
\hline $\begin{array}{l}\text { Destination } \\
\text { Quality }\end{array}$ & $\begin{array}{l}\text { Tourist } \\
\text { Satisfaction }\end{array}$ & 0.556 & 11.226 & 0.000 \\
\hline \multicolumn{2}{|c|}{ Constanta $=1.416$} & & & \\
\hline \multicolumn{2}{|c|}{ R Square $=.801$} & & & \\
\hline \multicolumn{2}{|c|}{ Adjusted R Square $=.799$} & & & \\
\hline \multicolumn{2}{|c|}{ F. statistic $=423.353$} & & & \\
\hline \multicolumn{2}{|c|}{ Significance $=0.000$} & & & \\
\hline
\end{tabular}

\section{Linear Regression Analysis}

Based on the results of regression analysis for the variable tourism experience and tourist satisfaction, the Beta value is 0.469 , the $\mathrm{t}$ value is 9,787 with a significance level of 0.000 . These results explain that the tourism experience and tourist satisfaction have a significant and unidirectional relationship. The value of the unidirectional relationship between tourist experience and tourist satisfaction is 0.469 or $46.9 \%$. This research is in line with research from [28]; [4]; [10]; [17]; [20] who describe the tourism experience that tourists perceive will directly impact the level of tourist satisfaction.

Outcome of analysis of regression for the variable destination quality and tourist satisfaction, the Beta value was 0.556 , the $t$ value was 11.226 with a significance level of 0.000 . These results illustrate that the link amongst tourist experience and satisfaction of tourist is linear and notable. The value of the unidirectional relationship with destination quality and tourist satisfaction is 0.556 or $55.6 \%$. This research supports research from [27]; [1]; [22]; [25]; [8]; [18] explain that the quality of the destination perceived by tourists will directly have an effect on the level of tourist satisfaction.

\section{CONCLUSIONS}

Consequence of the study can be stated that the better experience of tourist that is perceived by tourists when visiting culinary tourism destinations, it will directly have an impact on increasing tourist satisfaction. This encourages tourist destination managers to continue to innovate services and present a variety of supporting attractions that can make tourists increasingly frequent culinary tourism destinations. Then, the quality of culinary tourism destinations that are perceived by tourists is relatively good and will directly impact the level of tourist satisfaction. The perception of tourists on the quality of destinations, especially the supporting facilities provided by destination managers, is considered to be quite good. Destination managers still have to increase the provision of supporting facilities in culinary tourism destinations so that tourists still feel comfortable and safe when visiting these destinations.

\section{REFERENCES}

[1] Wang, Tz. Li., Tran, Kim Thi., and Tran, T. V. 2017. "Destination perceived quality, tourist satisfaction and word-of-mouth, Tourism". Tourism Review, Vol. 45 No. 2: pp. 227-241.

[2] Bramwell, B. 1998. "User Satisfaction and Product Development in Urban Tourism". Tourism Management, Vol.19 No. 1: pp. 35-47.

[3] Wirtz, D., J. Kruger, C. N. Scollon., and E. Diener. 2003. "What to Do on Spring Break? The Role of Predicted, On-line, and Remembered Experience in Future Choice". Psychological Science, Vol.14: pp. 520-524.

[4] Huang, S., and Hsu, C. 2009. "Effects of travel motivation, past experience, perceived constraint, and attitude on revisit intention". Journal of Travel Research, Vol. 48 No. 1: pp. 29-44.

[5] Shoemaker, S., and Lewis, R. C. 1999. "Customer loyalty: The future of hospitality marketing". International Journal of Hospitality Management, Vol. 18: pp. 345-370.

[6] Prayag, G., and Ryan, R. 2012. "Antecedents of tourists' loyalty to Mauritius: the role and influence of destination image, place attachment, personal involvement, and satisfaction". Journal of Travel Research, Vol. 51 No. 3: pp. 342-356.

[7] Kim, J. H., Ritchie, J. B., and McCormick, B. 2010. "Development of a scale to measure memorable tourism experiences". Journal of Travel Research, Vol. 51 No. 1: pp. 12-25.

[8] Tian-Cole, S., and Crompton, J.L. 2003. "A conceptualization of the relationships between service quality and visitor satisfaction, and their links to destination selection". Leisure Studies, Vol. 22: pp. 65-80.

[9] Bigne, J., Sanchez, M., and Sanchez, J. 2001. "Tourism image, evaluation variables and afterpurchase behavior: Interrelationships". Tourism Management, Vol. 22 No.6: pp. 607-616.

[10] Kim, H., Woo, E., and Uysal, M. 2015. "Tourism experience and quality of life among elderly tourists". Tourism Management, Vol. 46: pp. 465476.

[11] Hosany, S., and Prayag, G. 2013. "Patterns of Tourists' Emotional Responses, Satisfaction, and Intention to Recommend". Journal of Business Research, Vol. 66 No. 6: pp. 730-737. 
[12] Faullant, R., Matzler, K., and Mooradian, T.A. 2011. "Personality, basic emotions, and satisfaction: Primary emotions in the mountaineering experience", Tourism Management, Vol.32 No. 6: pp. 1423-1430.

[13] Sung, Y. J., Kim, Y.J., Ohyoon Kwon, O.Y., and Moon, J.H. 2010. "An Explorative Study of Korean Consumer Participation in Virtual Brand Communities in Social Network Sites, Journal of Global Marketing, Vol. 23 No. 5: pp. 430-445.

[14] Grappi, S., and Fabrizio, M. 2011. "The Role of Social Identification and Hedonism in Affecting Tourist Re-patronizing Behaviours: The Case of an Italian Festival". Tourism Management, Vol.32 No. 5: pp. 1128-1140.

[15] Petrick, J.F., Morais, D.D., and Norman, W. 2004. "An Examination of the Determinants of Entertainment Vacationers' Intentions to Revisit". Journal of Travel Research, Vol. 40: pp.41-48.

[16] Weed, M. 2005. "Sports tourism theory and method: concepts, issues and epistemologies, European Sport Management Quarterly, Vol. 5 No. 3: pp. 229-242.

[17] Kim, A.K., and Brown, G. 2012. "Understanding the relationships between perceived travel experiences, overall satisfaction, and destination loyalty", Anatolia-An International Journal of Tourism and Hospitality Research, Vol. 23 No. 3: pp. 328-347.

[18] Cole, S., and Illum, S. 2006. "Examining the mediating role of festival visitors' satisfaction in the relationship between service quality and behavioral intentions". Journal of Vacation Marketing, Vol.12 No. 2: pp. 160-173.

[19] Murray, D., and Howat, G. 2002. "The relationships among service quality, value, satisfaction, and future intentions of customers at an Australian sports and leisure centre". Sport Management Review, Vol. 5: pp 25-34.

[20] De Rojas, C., and C. Camarero. 2008. "Visitors' experience, mood and satisfaction in a heritage context: evidence from an interpretation center". Tourism Management. Vol. 29: pp.525-537.

[21] Chen, C. F., and Tsai, D. 2007. "How destination image and evaluative factors affect behavioral intentions". Tourism Management, Vol. 28: pp. 1115-1122.

[22] Rajaratnam, S.D., Nair, V., Sharif, S.P., and Munikrishnan, U.T. (2015). Destination quality and tourists' behavioural intentions: rural tourist destinations in Malaysia", Worldwide Hospitality and Tourism Themes, Vol. 7 No. 5: pp.463-472.

[23] Hui, T., Wan, D., and Ho, A. 2007. "Tourists' satisfaction, recommendation and revisiting Singapore". Tourism Management, Vol. 28 No. 4: pp. $965-975$.

[24] Petrick, J.F. 2004. "The roles of quality, value and satisfaction in predicting cruise passengers' behavioral intentions", Journal of Travel Research, Vol. 42 No. 4: pp. 397-407.

[25] Žabkar, V., Brenčič, M., and Dmitrović, T. 2010. "Modelling perceived quality, visitor satisfaction and behavioural intentions at the destination level". Tourism Management, Vol. 31: pp. $537-$ 546.

[26] Xia, W., Jie, Z., Chaolin, G., and Feng, Z. 2009. "Examining antecedents and consequences of tourist satisfaction: A structural modelling approach". Tsinghua Science and Technology, Vol. 14 No. 3: pp. 397-406.

[27] Setiawan, H. 2018. "Does Destination Image and Perceived Destination Quality Influence Tourist Satisfaction and Word of Mouth of Culinary Tourism". In Proceedings of the $4^{\text {th }}$ Sriwijaya Economics, Accounting, and Business Conference (SEABC 2018), pp. 20-28.

[28] Sangpikul, A. 2018. "The effects of travel experience dimensions on tourist satisfaction and destination loyalty: the case of an island destination", International Journal of Culture, Tourism and Hospitality Research, Vol. 12 No. 1: pp. 106-123. 